\title{
MONEY CREATION \\ AND THE REVOLUTION \\ Along the Path to Real Change
}

RODDY A. STEGEMAN*

When you store your belongings in a private locker, does the owner of the locker pay you? On the contrary, you pay the owner, for he is providing you with a service called safe-keeping. In effect, the owner holds your belongings safe until you take them back. So, why is it that you accept money from a bank to hold your money for you?

The obvious answer is that the bank is not holding your money; it is lending it out and rewarding you with a portion of what it collects in interest. If you are happy with this arrangement, you have likely sought out a bank in your neighborhood that provides you with the greatest return on your deposit. Unfortunately, there are several things very wrong with this type of transaction. Most important is that you are engaging in a transaction that is commercially unsound.

\section{I \\ NON-BINDING AGREEMENT}

You and your bank engage in a legally non-binding agreement when, on the one hand, your bank promises to return your deposit on demand, and on the other hand, loans a portion of it to others for a specified period of time. Contractually, these two acts are incompatible, as the same money cannot be both a demand deposit and a loan simultaneously. Either, you deposit

\footnotetext{
* Lecturer, King Abdul-Aziz University, Jeddah, Kingdom of Saudi Arabia (rstegemann@kau.edu.sa)
} 


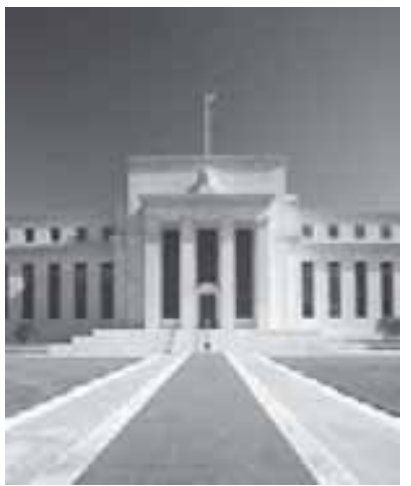

your money, reserve the right to demand it back at any moment, and pay the bank for holding it on your behalf. This is called a demand deposit. Or, you surrender your right to your money for a specific period of time, permit your bank to lend it to others, and receive interest for your risk and sacrifice. This is called a time deposit. Commercially, treating your demand deposit as money that can be loaned to others is not an enforceable contract, for the law insists that there must be mutual assent when two parties enter into an agreement. You and the bank are simply at odds when you expect to retrieve your money at any moment on demand, and the bank lends a portion of it to others for a fixed period. Legally speaking, both parties to the transaction do not agree to the same contractual terms in the same sense.

Unfortunately, you do not realize the weakness of this transaction until your bank tells you one day, «I am sorry sir, but your money is currently unavailable», and «We will notify you ma'am as soon as we are able», and then shuts its door until the government rescues it from dissolution. ${ }^{1}$

II

FRACTIONAL RESERVE BANKING AND COUNTERFEITING

We dislike people who counterfeit money for good reason; they are able to purchase things that we are unable by simply printing money for which we, in contrast, sacrifice time and effort in the work place to obtain. Now, banks counterfeit when they create money ex nihilo ${ }^{2}$ and loan it into existence. This illicit procedure

\footnotetext{
${ }^{1}$ Jesús Huerta de Soto (2012): Money, Bank Credit, and Economic Cycles. $3^{\text {rd }}$ Edition. Chapter 1 - The Legal Nature of the Monetary Irregular-Deposit Contract. Translated by Melinda A. Stroup. Auburn, Alabama: Ludwig von Mises Institute, pp. 1-36.

2 The term ex nihilo is Latin. It means out of nothing.
} 
is called fractional reserve banking and is sanctioned by government statute around the world. ${ }^{3}$ In brief, for every dollar (or other currency) you deposit in your bank, your bank is permitted to loan some very large fraction of it to someone else. What is left in the bank is called the bank's fractional reserve.

By way of illustration, say you deposit 100 dollars with your bank in the form of a demand deposit. Further assume, for the sake of simplicity, that the fractional amount that the bank is permitted to lend to someone else is $90 \%$ of what you deposit, and that you are the other person. This means that you can now spend 190 dollars where before you had only 100 dollars. If you were to take the 90 dollars received from your loan, and deposit it with the same or another bank, you could now borrow $90 \%$ of the 90 dollars that you just deposited - namely, 81 dollars. Repeating this process until there were nothing left to borrow, you could obtain access to 1000 dollars with your original deposit - ten times more than what you originally deposited!

At the end of each loan period you would have to return to the bank what you borrowed, and throughout the loan period you would have to pay the bank interest on the same. In addition, you would receive some of your interest payments back in the form of interest on each new deposit. Important is that for some period of time you would have access to somewhat under 900 dollars of additional money to spend in the market place. Also important is that the bank would retain some of your original deposit after you repay your debt with interest. «So, where is the counterfeit», you may ask, "After all, I pay back everything that I borrow plus interest.»

In order to understand the act of counterfeit in which your bank engages consider what happens when you return your money

\footnotetext{
${ }^{3}$ In the United States the central bank that oversees fractional reserve banking is not a single bank, but a group of 12 banks called the Federal Reserve System. The government body that oversees this system is the Federal Reserve Board, and its current chairperson is Ben Shalom Bernanke. In the US this entire system is commonly known as the FED. The photographic images displayed in this article are those of the Eccles Building in Washington, D.C., and the Federal Reserve Banks of San Francisco, St. Louis, and New York, respectively. The Eccles Building is where the Federal Reserve Board meets; it is the headquarters of the FED.
} 
to the bank. It does not disappear! Rather, the bank loans out the same 900 dollars to someone else, and does this as many times, as it is able, provided your deposit remains with the bank and the bank can find a borrower. Not only does your bank make a profit with each new loan, but there are 900 more dollars in circulation than there were before you left your money with the bank for safekeeping. Now, multiply this 900 dollars times 240 million employed US workers, and you can readily determine a very conservative estimate of the number of counterfeit dollars in circulation. This counterfeited money is a portion of our nation's money supply, and the system that produces it is called fractional reserve banking.

Setting aside government statute for the moment, there are only three commercially legitimate forms of money that a bank can lend: money that belongs to the bank, money that the bank borrows from others, and money that has been entrusted to the bank by its owners for the purpose of investment. Demand deposits fit into none of these three categories.

Money that belongs to a bank is money that the bank earns from the provision of services and the fees that it collects for their provision. For example, a bank legally lends money that it receives when you pay it to safeguard your valuables, cash a check, pay your bills, or perform any of a large number of other services. Other legitimate bank income is money received from the management of pooled funds whose owners bare the risk and reap the rewards of the investments that the bank manages on their behalf. These funds are called mutual funds. In both examples the bank receives

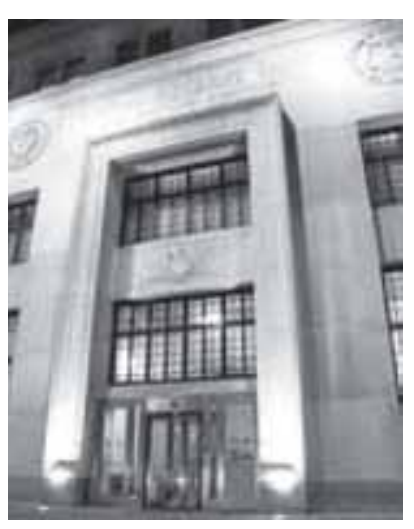
income for providing a service that it can then spend, save, or invest just like any other income earner.

Money that a bank borrows and then lends to others is also legitimate, but very different, because the bank's ownership of the money is temporary and must be returned after a fixed period of time. Money obtained by banks in this fashion is a risky business for both the depositor and the borrowing bank. It is risky to the depositor, for the bank 
could default or not pay the depositor in a timely fashion. It is risky to the bank, for the bank must not only pay the interest in a timely fashion, but must also repay the depositor when the loan principal becomes due no matter the behavior of those to whom the bank has further lent the money. This is the nature of a time deposit.

III

REAL AND NOMINAL WEALTH

Money, whether it be created ex nihilo and lent into existence by a private or central bank, or created ex nihilo and spent into circulation by a private individual or government as legal tender, is not wealth per se. Rather, it is a nominal claim on wealth. This claim is what economists commonly call nominal wealth, financial capital, or purchasing power. In contrast, real wealth includes tangible consumer goods, real capital (the machines, equipment and materials used in the production of other goods and services), human capital (the skills, talent, and knowledge of the owners, managers, and workers who produce these goods and services), tradable information, and natural resources such as land, water, mineral deposits, fossil fuels, and the like. An individual or group of individuals who hold money exercise a claim over any form of real wealth whose owner is willing to sell, and that the holder of money has a sufficient amount to buy.

IV

MONEY CREATION AND THE REDISTRIBUTION OF STOLEN WEALTH

The creation of money ex nihilo has the effect of diverting the ownership of real wealth from the anonymous many to a selected, nameable, but secretive few. This diversion is not obvious, for, if it were, most people would have demanded an end to it a long time ago.

As the amount of real wealth does not change when new money is created, the value of all existing claims to this wealth is 


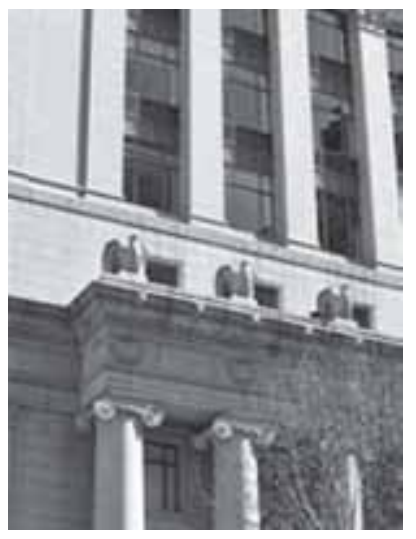

diminished. Accordingly, there are now more nominal claims to the same amount of real wealth, and some people enjoy a larger proportion of these claims than they did before. Indeed, with more money in circulation prices are bid up, and everyone requires more units of currency to purchase the same amount of goods and services (inflation). ${ }^{4}$ As the amount of currency that most of us holds is the same, most of us are poorer. Only those who are eligible to borrow from a bank have more, are able to purchase more, and thus command a greater proportion of our nation's wealth. Now, the borrower's eligibility for a loan depends on his ability to make good on his interest payments to the bank and to return the loan's principal when the borrowed sum becomes due; it does not depend on the borrower's contribution to the community on whose wealth the bank and the borrower have laid additional claims. Finally, the money that is lent into existence is nearly always invisible, as only the borrower and the lending bank are usually privy to what is borrowed and lent. This veil of secrecy also applies to the relationship between the lending depositor and the borrowing bank.

\section{$\mathrm{V}$ \\ BANK PRUDENCE, MARKET SHARE, AND THE FALLACY OF COMPOSITION}

Like other firms banks compete among themselves for customers by offering the best quality and service for the lowest possible price. The product that banks sell when they lend money into existence is loans; they make their product attractive to consumers

\footnotetext{
4 Although visible, inflation is neither readily perceived, nor always felt depending on the flexibility of market prices. Typically, those on fixed incomes such as hourly wage earners and retirees are negatively effected.
} 
by making it easy to borrow and pay back. Typically banks do not lend to anyone for any reason, because they must have a reasonable chance of getting back what they lend in a timely fashion. As a result, banks are expected to be prudent. For example, they usually lend to people with a good credit rating and avoid those with a bad one. Further, banks are more likely to loan money borrowed for the purpose of buying tangible, recoverable objects, or to lend to borrowers who can produce collateral as a guarantee for repayment. Although a lack of prudence on the part of a bank is likely to lead to failure, prudence is no guarantee that a bank will not fail. Indeed, there are a whole host of negative market factors called externalities to which individual banks contribute when they create and lend money into existence.

Since what is not deposited in one bank is likely deposited in another, banks that offer the highest interest rate of deposit tend to attract more depositors and larger deposits. As a result, these banks have the potential to lend more money into existence and capture a larger share of the loanable funds market. Furthermore, since governments typically insure the money of depositors, they encourage these latter to place their money with banks that pay the highest interest rate of deposit no matter the risk to themselves or the banks at which they deposit their money. ${ }^{5}$ As a consequence, these banks incur higher costs and greater risk, because the interest payments to their depositors must be paid no matter the bank's ability to make good on the sale of additional and larger loans. Finally, if a bank does not lend money, its likelihood of meeting its obligations to its depositors will necessarily decrease for lack of sufficient revenue. For this reason banks have a built-in incentive to loan money whenever it is profitable to do so, even when the implied risks are not always clear. ${ }^{6}$ As the market conditions that prevail at the time a sum

\footnotetext{
5 This is an example of moral hazard created by government intervention.

6 Profitable in this context means that the interest received on money lent is sufficiently higher than the interest paid on money borrowed (eg. time deposits). In the short-run, sufficient means that the difference between these two rates covers, at minimum, the transaction cost of receiving and holding deposits and dispersing, monitoring, and retrieving loans. In the long run, the cost of maintaining the banks' physical assets and return on equity must also be covered.
} 
of money is lent and those that prevail at the time the money must be paid back are subject to change, the risks are many. Similarly, the situation of individual depositors and borrowers does not remain the same over time.

What makes the fractional reserve system and the creation of money ex nihilo so pernicious is that all banks tend to behave similarly under similar economic conditions. When a borrower goes to one bank for a new loan and not to another, it deprives the other banks of potential revenue and profit. In order to prevent this from occurring the other banks are pressured into making their deposit and loan opportunities more attractive as well. Accordingly, if many banks are operating in the same community, and all banks lower their lending requirements simultaneously, then many more borrowers enter into the market. This, of course, increases the amount of money in the system, as well as the level of spending. ${ }^{7}$ This induced spending increase is called the nominal wealth effect, and the joint competitive behavior that brings it about is a fallacy of composition. The pernicious effect of these phenomena will soon be made clear.

\section{THE PRICE OF, AND MARKET FOR LOANABLE FUNDS}

When we borrow, we bet our future against the present in the belief that the future will be as good, if not better than when we bet. This is a gamble that not everyone can take at the same time, because borrowers consume more in the present than what they produce. In short, others must consume less than what they produce in order to fund the borrowers, This latter is called saving. As we save, we accumulate nominal claims (money) to real wealth. We set these claims aside to spend at a later date or for others to borrow in the present. The money that we set aside for ourselves

7 If the fractional reserve system were always operating at its peak - i.e., every bank were always lending everything, but its required fractional reserve - , then there would be no change in the money supply. This, of course, is a condition that no central bank or government can ever guarantee. 
can be used for future transactions, emergencies, or retirement. What we set aside for others is generally used for the purchase of current factors of production. These factors of production are typically used by firms to produce even more real wealth for the future. ${ }^{8}$ This latter use of our savings is called investment; it is what permits the maintenance and sustainable growth of the real economy.

The price of borrowing and lending is determined by the demand for, and supply of loanable funds - investment and saving, respectively. In the absence of fractional and federal reserve

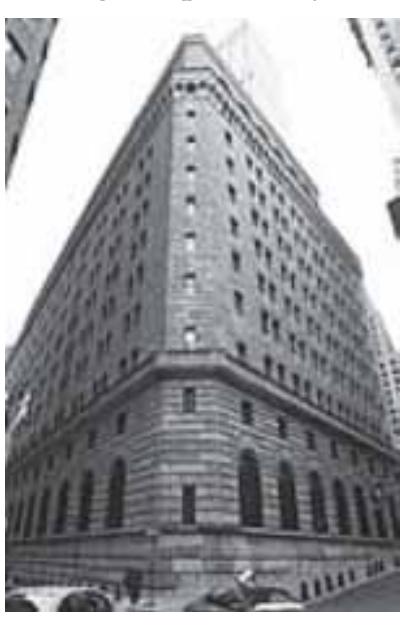
lending ${ }^{9}$ the nominal worth of traded loanable funds is equal to the amount of real savings that savers are willing to invest and firms are willing to borrow. The equilibrium price that results from the tug-of-war between the demand for, and supply of loanable funds is called the real rate of interest. When the real rate of interest is high, savers are willing to lend more, and investors are willing to borrow less. When the real rate of interest is low, savers are less willing to lend, and investors are more willing to borrow.

When firms borrow, they do so in the belief that their future revenue will cover their immediate and future costs. When

8 Consumers who purchase real estate and durable goods, such as automobiles and household appliances, also engage in a form of investment. This is because most of the benefits received from the purchase of a home, automobile, or household appliance are not immediate, but accrue long into the future.

${ }_{9}$ Just as private banks loan money into existence, so too, do central banks. In the United States this is achieved when the US Treasury issues new debt and sells it to the Federal Reserve system in exchange for cash. Typically, this same debt is further sold by the FED to large commercial money banks and then traded in the private sector. These sales absorb the new money injected into the economy by our government when it spends the money raised from the issue of the new debt. By absorbing the new money, the money supply is held relatively constant and rampant inflation is avoided. The downside of these sales is lower bond prices, higher bond yields, and higher interest rates that make it more difficult for the private sector to borrow. The government is said to choke out private investment. 
consumers borrow, they belief that their current and future benefit flows will exceed the cost of their regularly paid installments. In both cases, the borrowers assume that they will be able to meet their interest payments and return the principal when it becomes due. These are very imporant assumptions that depend on many factors some of which are well beyond the control of investors - hence, the gamble. In the absence of inflation wise investors use current and historical factor and product prices and the current and likely future cost of borrowing as their guides for estimating their future revenue, benefits, and costs. Their profit or return on investment is based on the difference between these benefits and costs. When the cost of current borrowing is low relative to other costs, firms can expect higher profits and consumers a better return on their investment.

Now, when banks lend money into existence they increase the supply of loanable funds above the level of real savings available for lending. In effect, they signal to investors that there is more real savings in the economy than there truly is. As a result, investors borrow and invest more than savers are willing to lend, and another, but different tug-of-war ensues between real investment and real consumption. It is this latter tug-of-war that necessarily ends in disaster.

VII

\section{THE EVER RECURRING BOOM AND BUST CYCLE}

Booms usually begin when banks lend into existence money that exceeds the value of real savings at current prices. This can occur whenever there exists within the banking system cash reserves that exceed the minimum reserve requirement set by central banks, and banks perceive an opportunity to increase their market share and profit through increased borrowing and lending. Obviously, perhaps, such opportunities are numerous and not limited to those mentioned in the previous section. ${ }^{10}$ As a result, booms and

10 Though the innovative packaging of already existing claims to a nation's real wealth, banks can create nominal wealth that exceeds even that available through the 
their inexorable counterpart busts are inevitable under a fractional reserve system. Not only are they inevitable, but they pass through predictable stages that typically begin when firms first borrow in excess of real savings. Important is that the inflation that results is not ubiquitous at first, as it takes time for it to work its way through the system. Moreover, the path that it takes is crucial.

Firms use their borrowed money (nominal claims to real wealth) to purchase already, or not yet employed real factors of production for use in their new investment projects. ${ }^{11}$ In order to draw these factors away from their current use firms offer prices that exceed these factors' current market value. Firms can afford these prices because they obtain their loans below the market's real rate of interest - in other words, at the rate of interest charged by banks when they issue new money in excess of the current market worth of real savings. The sale and purchase of the aforementioned higher priced factors injects this money into the real economy. This nominal wealth is then used by the previous owners of these factors to increase their nominal savings ${ }^{12}$ and real consumption. This increase in nominal savings is further used by banks to provide still more ready cash in excess of their fractional reserves. In addition, the increase in consumption draws down existent merchant inventories and new product orders follow. This necessarily results in increased demand for other, already or not yet employed factors of production in other market sectors. To the extent that there is an increase in the number of real goods and services produced, these goods and services are rarely sufficient to satisfy the needs of both the new investment projects and the increase

fractional reserve system. This is the reason that all nominal claims to wealth that exceed the level of real wealth must be prohibited - not just those generated through the fractional reserve system.

11 Although we generally assume that all employable factors of production are already employed, this need not be the case. Important is that the factors crucial to the success of the new investment projects are already employed.

12 Nominal savings are the money that income and revenue earners deposit with banks. Once again, these are only claims on real goods, property, and services that may or may not be already employed. In order for new, sustainable investment to take place, there must also be a rise in real savings. This implies a decrease in real consumption - not an increase! 
in real demand in the rest of the economy. As much time is required before the new investment projects can bear fruit, a shortage of everything results, and the prices of all goods and services are bid up. ${ }^{13}$

In order to meet the higher price of everything the original investing firms must now borrow additional money.Eagerly, banks rally to their call by creating and lending still more money into existence, but at ever higher rates of interest, as they exhaust their reserve potential. Soon these firms realize that they can no longer afford to borrow. There is simply not enough real savings in the system to satisfy both the real needs of their projects and the increased demand for real final goods and services in the rest of the real economy. ${ }^{14}$ The result is devastating.

The factors of production that were not consumed by the new investments become idle, and the owners of these factors find themselves surrounded by higher prices and no income. Their demand for final goods and services falls, and with this decrease the inventories of final goods begin to rise. Workers who have been working overtime to meet the higher demand in all goods and services return to their normal schedules; the resulting fall in income causes a further drop in demand for many other real goods and services. This general fall leads to decreased revenue and profits for many firms. In an effort to maintain their current rates of return firms begin looking for ways to cut costs. Additional

13 Roger W. Garrison (2001): Time and Money: The Macroeconomics of Capital Structure. London and New York: Routledge. This book is an excellent introduction to the theory of the Austrian business cycle (ABC) developed by Friederich Hayek and his mentor Ludwig von Mises. It is a great resource for anyone with a solid foundation in Keynesian macroeconomic theory and the Monetarist School. For those with little economic background Jesús Huerta de Soto's book Money, Bank Credit, and Economic Cycles may provide a more easily understood introduction.

14 Across-the-board inflation is not an inevitable result of an ever increasing money supply. During the Roaring Twenties - the boom period that preceded the Great Depression - the general price level remained relatively stable. This is because the boom was accompanied by a simultaneous rapid growth in real goods and services brought about by the rapid introduction of technological innovation. Had there been no increase in the money supply, the price of goods, services, and factor inputs would have fallen. The over supply of nominal claims on our nation's wealth did eventually surface in the stock market where stock prices continued to rise until just before the onset of the bust. 
workers are laid off and the owners of other factor inputs experience a fall in income. Firm revenue continues to falter. Fallen income and revenue also mean falling nominal savings. Banks retire whatever loans that they are able, and no additional loans are made. The money supply shrinks, and previous claims on the nation's output begin to disappear. Firms that were reluctant to lower prices as inventories rose, now find it necessary to lower prices in order to bolster sales and stave off fallen revenue. In some cases this strategy works, in others it does not. More fallen revenue and cuts in production result, and the employment of workers and other factors of production diminishes further. Nominal savings continue to decline, as consumers struggle to meet their interest payments on durable goods purchases that they can no longer afford. Banks find it difficult to meet their fractional reserve requirements. The money supply (claims on real wealth) shrinks further, everyone feels poorer (nominal wealth effect), and the economy experiences a general slowdown. For many, the result is catastrophic.

\section{VIII \\ THE LOSERS AND THE WINNERS}

Though most everyone loses during an economic downturn, the damage is uneven and there are some real winners.

Those most hurt are, of course, workers who suddenly find themselves in the streets without employment. Unemployment insurance is rarely enough and households begin to dig into their nominal savings. By the time the recession is over many workers have drained their nominal savings and sold some of their real assets just to survive - this, despite important cuts in consumptive spending. If workers are fortunate, able to ride out the storm, and can find new employment when the economy recovers, the cycle repeats itself. Like Sisyphus ${ }^{15}$ workers save during each boom

15 Sisyphus was punished in Hades for his misdeeds. His sentence was the eternal and repetitive task of rolling a large stone to the top of a hill only to watch it roll back down. 
only to watch their savings disappear with each inevitable and subsequent bust. By the time they leave the work force permanently there is little left for them and their children. Unable to build lasting claims to their nation's output, a lifetime of work leaves them with little satisfaction.

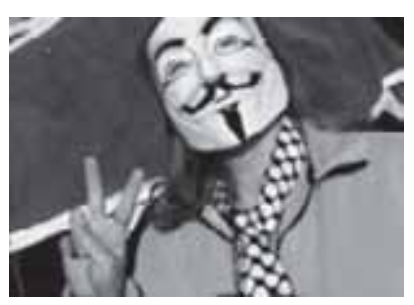

In stark juxtaposition firms that are able to survive the inevitable downturn are able to gobble up the assets of less fortunate firms at bargain prices. When the economy buoys they are well poised to produce real wealth and earn profits at levels higher than they were able before the downturn began. If they are fortunate, they can repeat this process with each new boom and bust cycle. When the owners and managers of these firms reach retirement they are much better off than when they started early in life, have provided well for their children, and can bequeath these latter with a sizable inheritance. In time a sizable income gap grows between those who are able to save and those who are not.

The owners of our private banks are the most consistent winners as they retain their profits from the boom and reap the rewards of taxpayer bailouts from governments that depend on the money that banks create in order to subsidize their often enormous deficits.

IX

\section{THE ROLE OF GOVERNMENT}

Many people rightfully look to government to rectify the above social injustice, but unfortunately for the wrong solution. The cure for the above calamity and perversion is to prevent the boom and bust cycles that bring these about. ${ }^{16}$ The only way that this can

16 The extraordinary wealth of America's top one and top one tenth of one percent is still another story and no less important. Though both stories are rooted in financial and government corruption, the story told in this essay is much better and well-documented in Jesus Huerta de Soto's Money, Bank Credit, and Economic 
be achieved is by denying, rather than subsidizing the counterfeiting of money in the name of unsustainable real growth and illusory social and economic progress for most workers.

By eliminating the statutory privilege granted by our central governments to banks and other financial institutions these latter would no longer be able to create money ex nihilo and lend it into existence. Further, by preventing our central governments from printing money in excess of the value of real savings at current prices the ever increasing income gap and pernicious boom and bust cycles that contribute to this gap would end.

Cycles. 2009. Translated by Melinda A. Stroup. Auburn, Alabama: Ludwig von Mises Institute. 